\title{
The half-life of immunoglobulin mRNA increases during B-cell differentiation: a possible role for targeting to membrane-bound polysomes
}

\author{
John O. Mason, ${ }^{1}$ Gareth T. Williams, and Michael S. Neuberger \\ MRC Laboratory of Molecular Biology, Hills Road, Cambridge CB2 2QH, UK
}

\begin{abstract}
The increase in abundance of immunoglobulin heavy-chain (IgH) mRNA that accompanies development of a B cell into a plasma cell is mainly due to post-transcriptional events. By constructing $\mu$ genes, whose expression is under inducible control, we determined the half-life of pulsed $\mu$ transcripts to be $\sim 20 \mathrm{hr}$ in plasmacytoma hosts and $\sim 3 \mathrm{hr}$ in B-cell lymphomas. Interestingly, a $\mu$ gene with a mutated signal sequence that is found on free (rather than membrane-bound) polysomes decays in the plasmacytoma host with a shortened half-life of 3 hr. Thus, a change in the turnover rate of IgH mRNA plays an important role in the cell-type specificity of immunoglobulin gene expression; this change may be a consequence of the fact that IgH mRNA is located in the membrane-bound polysome fraction.
\end{abstract}

[Key Words: mRNA stability; gene expression; secreted protein; endoplasmic reticulum; B-cell differentiation; immunoglobulin genes]

Received April 19, 1988; accepted May 19, 1988.

Immunoglobulin genes are exclusively expressed in lymphoid cells. This restricted pattern of immunoglobulin heavy-chain (IgH) gene expression is due, at least in part, to cell-type specificity of the immunoglobulin gene enhancer (Banerii et al. 1983; Gillies et al. 1983; Neuberger 1983) and the $V_{\mathrm{H}}$ gene promoters (Mason et al. 1985; Grosschedl and Baltimore 1985). However, the pattern of $\mathrm{IgH}$ transcription changes within the B-cell lineage. In particular, the differentiation of a $B$ cell that bears surface IgM into a plasma cell that secretes IgM is accompanied by a large increase in the abundance of the mRNAs for both heavy and light chains (Perry and Kelley 1979).

From transfection assays it appears that this differentiation is not accompanied by a large increase in the activity of the IgH enhancer (Mason et al. 1985; Gerster et al. 1986). Two main lines of evidence indicate that posttranscriptional processes play a major role in effecting the increase in abundance of IgH mRNA. First, comparison of an IgG-expressing plasmacytoma with an IgMexpressing B-cell lymphoma has shown that a 25 -fold difference in the steady-state levels of cytoplasmic IgH mRNA is associated with only a 6-fold difference in the level of IgH nuclear RNA in the two cell lines (Perry and Kelley 1979). Second, measurements of the RNA polymerase density across the IgH locus in different cell

'Present address: Department of Microbiology and Immunology, University of California Medical Center, San Francisco, California 94143 USA. lines have indicated that the increase in IgH mRNA levels is not associated with a corresponding increase in the RNA polymerase loading across the locus (Gerster et al. 1986; Kelley and Perry 1986).

In this work we demonstrate that post-transcriptional modulation is effected at the level of the turnover of IgH mRNA in the cytoplasm; we present further evidence suggesting that the decreased rate of IgH mRNA turnover in plasmacytoma may be correlated with the increased amount of endoplasmic reticulum and the fact that IgH mRNA is located in membrane-bound polysomes.

Results

Post-transcriptional events are almost exclusively responsible for effecting the B-cell to plasma cell increase in $\operatorname{Ig} H \mathrm{mRNA}$

It is clear from previous work that post-transcriptional events play a major role in effecting the increase in abundance of IgH mRNA that accompanies B-cell differentiation (Perry and Kelley 1979; Gerster et al. 1986; Kelley and Perry 1986). However, many of these experiments compared cell lines that express different IgH genes, sometimes of different heavy-chain class. Therefore, to make a quantitative assessment of the extent to which post-transcriptional events are important, we made use of a matched pair of cell lines, WEHI231 and MPC11 1 WEHI. WEHI231 is an IgM-expressing mouse 
B-cell lymphoma (Gutman et al. 1981); MPC11 $\times$ WEHI is a hybrid created by fusing WEHI231 with the $\operatorname{IgG} 2_{b}$ expressing plasmacytoma MPC11, which does not retain a $\mu$ gene itself (Raschke et al. 1979). This hybrid retains the plasmacytoma phenotype and secretes large quantities of the WEHI231-derived IgM.

Nuclear run-off assays were performed to compare the RNA polymerase density across the $J_{\mathrm{H}}-C \mu$ region in WEHI231 and MPC11 $\times$ WEHI. Both sense transcription and antisense transcription were measured. Transcripts of the genes encoding four metabolic enzymes were monitored to provide controls. The results (Fig. 1A) indicate that most of the transcription through the $C \mu$ exons occurs on the sense strand. However, through the $J_{\mathrm{H}}$ cluster, antisense transcription and sense transcription are of a similar order. It is known that sterile $\mathrm{IgH}$ transcripts exist that initiate in the region of the IgH enhancer (Lennon and Perry 1985); the antisense transcription through $I_{\mathrm{H}}$ may well be a consequence of the fact that polymerase molecules loading at the enhancer can proceed in either direction in the absence of a TATA element (e.g., see Calabi and Neuberger 1985).
When the RNA polymerase density across the $C \mu$ exons (as determined in several experiments) was compared to the controls (Fig. 1A), it was seen that WEHI231 and MPC11 $\times$ WEHI gave extremely similar results, with the loading through the $I_{\mathrm{H}}-C \mu 3 / 4$ region in the hybrid averaging between 1 and 1.5 times that in WEHI231 (quantitation was performed as described under Materials and methods). Thus, the expressed $\mu$ genes of the B-cell lymphoma and of the hybridoma must be transcribed at similar rates.

Parenthetically, it is interesting to note that these nuclear runoff results indicate that even in a plasmacytoma that contains high steady-state levels of IgH mRNA, the RNA polymerase loading on the IgH locus is of a similar order to that on the genes for several metabolic enzymes.

As shown above in the context of antisense transcription, one cannot assume that the polymerase molecules detected across the $I_{\mathrm{H}}-C \mu$ locus have all loaded on at the $V_{\mathrm{H}}$ promoter. Therefore, to confirm the conclusions drawn from the runoff assays, we compared the steadystate levels of nuclear $\mathrm{k}$. RNA in the two cell lines with
Figure 1. (A) Nuclear runoff assays of $\operatorname{IgH}$ transcription. Labeled RNA from the runoff incorporations was hybridized to filters that contained DNA probes from M13 subclones for both sense $(+)$ and antisense $(-)$ transcription of the $I_{\mathrm{H}}-C \mu$ region or c-myc exon 2 , as well as DNA from pBR322 clones containing inserts of cDNAs for rat lactate dehydrogenase (LDH), enolase (ENOL), glyceraldehyde-3-phosphate dehydrogenase (GAPDH), and triose phosphate isomerase (TIM) (Matrisian et al. 1985). The autoradiographs depicted are from a parallel analysis of WEHI231 and MPC11 $\times$ WEHI. A restriction map indicates the derivation of the probes for $J_{\mathrm{H}}-C \mu$ transcripts that avoid repetitive sequences [ $i$ and ii (Richards et al. 1983)]. Restriction sites: BamHI (B); BglII (Bg); HindIII (H); EcoRI (R); SacI (S); XbaI (X); XhoI (Xh). A bar chart indicates the RNA polymerase density relative to the controls and was calculated from an average of three experiments, as described in Materials and methods. $(B)$ Comparison of cytoplasmic and nuclear $\mu$ RNA levels in WEHI231 (W) and MPC11 $\times$ WEHI $(\mathrm{M} \times \mathrm{W})$ by Northern blot analysis. Total cytoplasmic $(20 \mu \mathrm{g})$ and total nuclear $(50 \mu \mathrm{g})$ RNAs were probed with a nick-translated M13 clone containing an HpaII fragment of mouse $\mu$ cDNA that extends from the $C \mu 2$ to the $C_{\mu} .4$ domain. The hybrids in the cytoplasmic RNA sample were washed off, and the filter reprobed with the rat lactate dehydrogenase (LDH) cDNA clone. The positions of the transcripts for membrane $\left(\mu_{m}\right)$ and secreted $\left\langle\mu_{s}\right\rangle$ chains are indicated, and their identity has been confirmed in other experiments using specific probes.
A
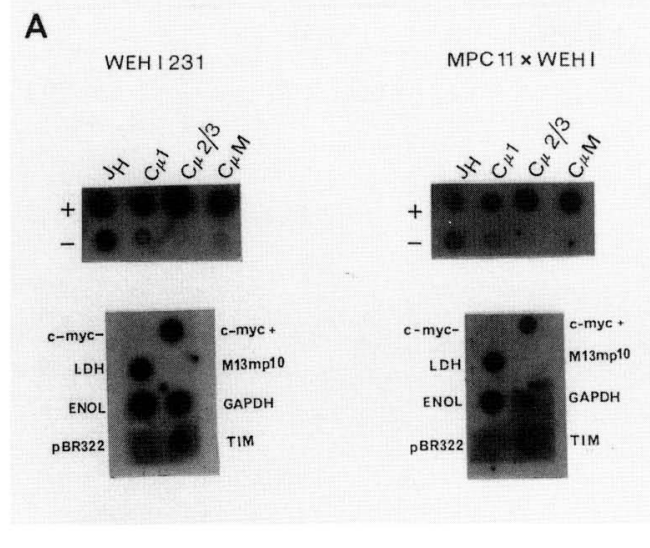

B

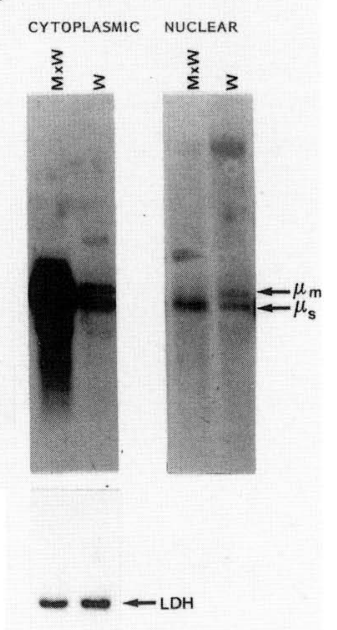

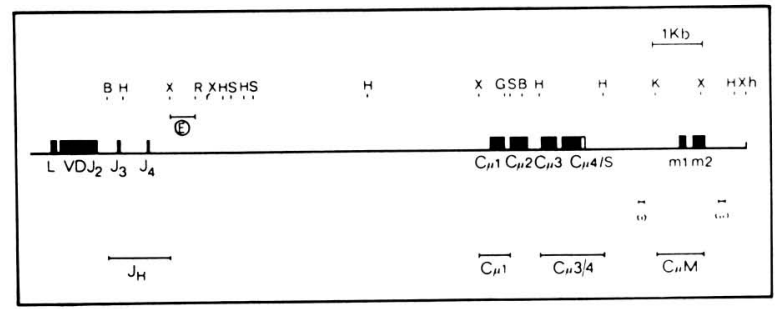

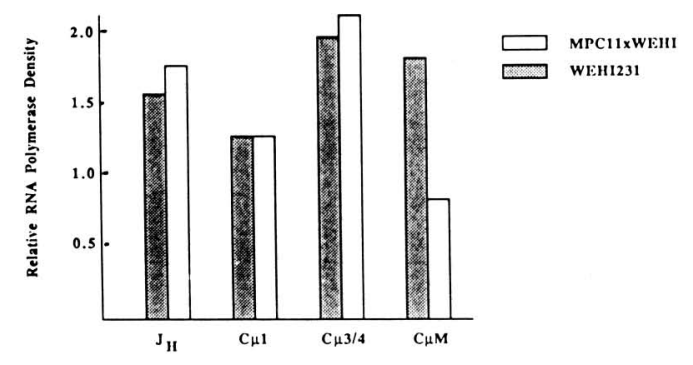


the cytoplasmic levels. The results (Fig. 1B) demonstrate that the difference in cytoplasmic $\mu$ mRNA levels between the two cell lines ( 15 -fold, as measured by densitometry) is considerably greater than the difference in steady-state nuclear $\mu$ RNA levels (1.6-fold). This indicates that much of the difference in cytoplasmic $\mu$ mRNA levels between WEHI231 and MPC11 $\times$ WEHI must be attributable to differences in cytoplasmic mRNA turnover, mRNA export, or late nuclear events.

\section{The stability of $\mu$ mRNA changes during B-cell differentiation}

Preliminary experiments to measure the half-life of $\mu$ mRNA carried out using the transcription inhibitor actinomycin $\mathrm{D}$ were unsuccessful. The half-life could be demonstrated to be $>1.5 \mathrm{hr}$ in WEHI231 and $>3 \mathrm{hr}$ in MPC11 $\times$ WEHI, but the toxicity of the drug precluded upper limits being placed on these estimates. Thus, in both cell lines, $\mu$ mRNA disappeared with similar kinetics to actin or lactate dehydrogenase mRNAs over a range of actinomycin concentrations. Therefore, to measure the mRNA half-lives, we constructed a plasmid, pSV-HS $\mu 1$ (Fig. 2A), which directs the synthesis of $\mu$ mRNA under the control of the Drosophila hsp70 heat shock promoter. This plasmid was transfected into plasmacytomas $5558 \mathrm{~L}$ and MPC1 $1 \times \mathrm{WEHI}$, as well as into the B-cell lymphomas WEHI231 and A20. Expression of the introduced $\mu$ gene could be induced effectively by heat-shocking (Figs. 2 and 3); Northern blot analysis (not shown| revealed that the $\mathrm{HS} \mu$ RNAs produced after the heat shock were processed to yield both $\mu_{m}$ and $\mu_{s}$ mRNAs in a ratio that was appropriate to the cell type /a slight excess of $\mu_{m}$ in WEHI231 but a large excess of $\mu_{s}$ in the plasmacytoma). Following a 1-hr heat induction, the level of $\mu$ mRNA in the transfectants was measured as a function of time (Figs. 2B and 3A). The $\mu$ mRNA is induced by heat shock and persists in the cytoplasm of the plasmacytoma transfectants for well over a day. That this persistence of cytoplasmic $\mu$ mRNA is a consequence of its stability rather than continued synthesis is indicated by the fact that although abundant cytoplasmic transcripts are still found $31 \mathrm{hr}$ after the end of the heat shock, nuclear $\mu$ transcripts have decayed away long before then (Fig. 2C). Furthermore, hsp70 transcripts are detected at the end of the heat induction but have decayed away by $4 \mathrm{hr}$ (not shown). Comparing the profiles of the inductions obtained in independent cloned transfectants of $5558 \mathrm{~L}$ and MPC11 $\times$ WEHI and restricting the analysis to the fate of the cytoplasmic $\mathrm{HS} \mu$ mRNA starting from $3 \mathrm{hr}$ after the end of the heat shock so as to minimize the effect of any artifacts caused by the heat shocking itself gives values of 20,12, and 19 $\mathrm{hr}(\mathrm{J} 558 \mathrm{~L})$ and $14 \mathrm{hr}$ (MPC11 $\times$ WEHI) for the half-life of heat-induced $\mu$ mRNA (Fig. 4). Analogous experiments on the WEHI231 and A20 transfectants (Fig. 3A) gave values of 3.2, 3.5, and $2.4 \mathrm{hr}$ (WEHI231) and $3.1 \mathrm{hr}$ (A20) for the $\mu$ half-life in the B-cell lymphoma host (Fig. 4). Similar conclusions were obtained from Northern blot analysis (not shown).
The initial choice of heat shock as the promoter to use for these experiments was dictated by preliminary experiments, which indicated that the heat-shock promoter gave a good induction of transcription with an extremely low or undetectable basal level of activity. However, the rapid disappearance of heat-induced $\mu$ transcripts in the B-cell transfectants made us anxious to confirm that this disappearance was indeed a consequence of the natural instability of IgH mRNA in these cells, rather than being a bizarre side effect of the heat shock itself, somehow affecting the heat-induced (but not the constitutive) IgH transcripts specifically in a Bcell background. Therefore we made constructs in which IgH transcription is driven by the metallothionein promoter (MT $\mu$ mRNA). Here we found that WEHI231 transfectants contained a high basal level of $M T \mu$ mRNA that could, however, be augmented by incubating the cells with heavy metals (Fig. 3B). After this induction was terminated with chelating agents, the levels of $M T \mu$ mRNA returned to background in $\sim 6 \mathrm{hr}$. These assays clearly support the earlier results, indicating a half-life of IgH mRNA in WEHI 231 of $\sim 3 \mathrm{hr}$. We have not managed to obtain a clear induction over background of MT $\mu$ transcripts by analogous treatment of I558L transfectants. This may simply be a consequence of the increased stability of IgH mRNA in these cells, thus leading to a higher basal level of expression.

\section{A mutant $\mu$ mRNA on free polysomes has a short half-} life

What might be the molecular basis of the differential half-life of the $\mu$ mRNA in the two cell types? Comparison of WEHI231 and MPC11 $\times$ WEHI in the electron microscope immediately reveals that the hybrid contains an extensive array of endoplasmic reticulum that is not readily detected in WEHI231. Therefore, one possibility is that targeting to the secretory apparatus plays a role in the stabilization of $\mu$ mRNA. As a preliminary test of the feasibility of this hypothesis, we analyzed transcripts encoded by plasmid pSV-HS $\mu^{*}$ (Sitia et al. 1987), which is a derivative of plasmid pSV-HS $\mu$ 1. In plasmid $\mathrm{pSV}-\mathrm{HSV} \mu^{*}$, the $\mu$ signal sequence has been mutated so as to destroy its hydrophobic nature (Fig. 5A). The $\mu^{*}$ chains encoded by this plasmid are synthesized on free polysomes, do not become glycosylated, do not associate with immunoglobulin light chain, and are turned over rapidly in the cytoplasm (Sitia et al. 1987). Following heat induction of transfected J558L cells, $\mu^{*}$ mRNA turns over with a half-life measured as 3.1, 3.3, and $3.8 \mathrm{hr}$ in different experiments (Figs. 4 and 5A). This contrasts with an average half-life of $\sim 20 \mathrm{hr}$ obtained with wild-type $\mu$ mRNA. It is therefore clear that $\mu^{\star}$ mRNA on free polysomes in a plasmacytoma has a short half-life, comparable to that of the wild-type $\mu$ mRNA in a B-cell lymphoma. In the WEHI231 B-cell lymphoma host, however, $\mu^{*}$ transcripts decay with kinetics that are apparently similar to those of $\mu$ transcripts in the same cell.

If it is assumed that $\mu$ mRNA is exported to the cyto- 
Figure 2. Decay of newly synthesized $H S \mu$ transcripts in transfected plasmacytoma cells. (A) Structure of pSV-HS $\mu 1$. This plasmid is identical to pSV-V $\mu \mathrm{l}$ (Neuberger 1983), except that the $V_{\mathrm{H}}$ promoter region of $\mathrm{pSV}-\mathrm{V} \mu \mathrm{l}$ from the EcoRI site upstream of the promoter to the Sau3AI site spanning the transcription start has been replaced by the EcoRI-BglII fragment of plasmid pF1 (Pelham 1982), which includes the Drosophila hsp70 promoter and 60 nucleotides of $t k$. Restriction sites are abbreviated as indicated in the legend to Figure 1. $(B)$ Induction and decay of $\mathrm{HS} \mu$ transcripts in clones of $\mathrm{J558 \textrm {L }}$ and MPC11 $\times$ WEHI cells transfected with pSV-HS $\mu 1$. Cells were heat-shocked at $42^{\circ} \mathrm{C}$ for $1 \mathrm{hr}$ from times $t=0$ to $t=1$, diluted into eight volumes of medium that had been prewarmed at $32^{\circ} \mathrm{C}$, and incubated further at $37^{\circ} \mathrm{C}$; cytoplasmic RNA was prepared at the indicated times. Under these conditions, both lines experience practically no loss of viability. $\mathrm{HS} \mu$ transcripts were assayed using a probe extending from the $\mathrm{V}$ region back through the hsp70 promoter; a reference (ref) is provided by a probe detecting transcripts from a heat shock cognate gene, the levels of which remained constant. Markers (M) are provided by an end-labeled HpaII digest of pBR322. (C) Comparison of nuclear and cytoplasmic $\mathrm{HS} \mu$ transcripts following induction of a pSV-HS $\mu 1$ transfectant of $\mathrm{J558 \textrm {L }}$. Cells were induced as described above, and cytoplasmic and nuclear transcripts were assayed at the times indicated. The level of mRNA for immunoglobulin $\lambda$ light chains provided a reference.

plasm at a similar rate in MPC1 $1 \times$ WEHI and WEHI231, a difference in the steady-state levels of cytoplasmic $\mu$ mRNA in the two cell lines could result if a difference in the amount of endoplasmic reticulum means that a smaller proportion of the exported $\mu$ mRNA in WEHI231 is stabilized by targeting to the secretory apparatus. If so, it is to be expected that a higher proportion of steady-state $\mu$ mRNA would be found on free polysomes in WEHI231 than in MPC11 $\times$ WEHI. To investigate this, RNA was prepared from membranebound and free polysomes from both WEHI231 and MPC1 $1 \times$ WEHI; the abundance of $\mu$ and c-myc mRNA in the samples was measured, with the c-myc serving as

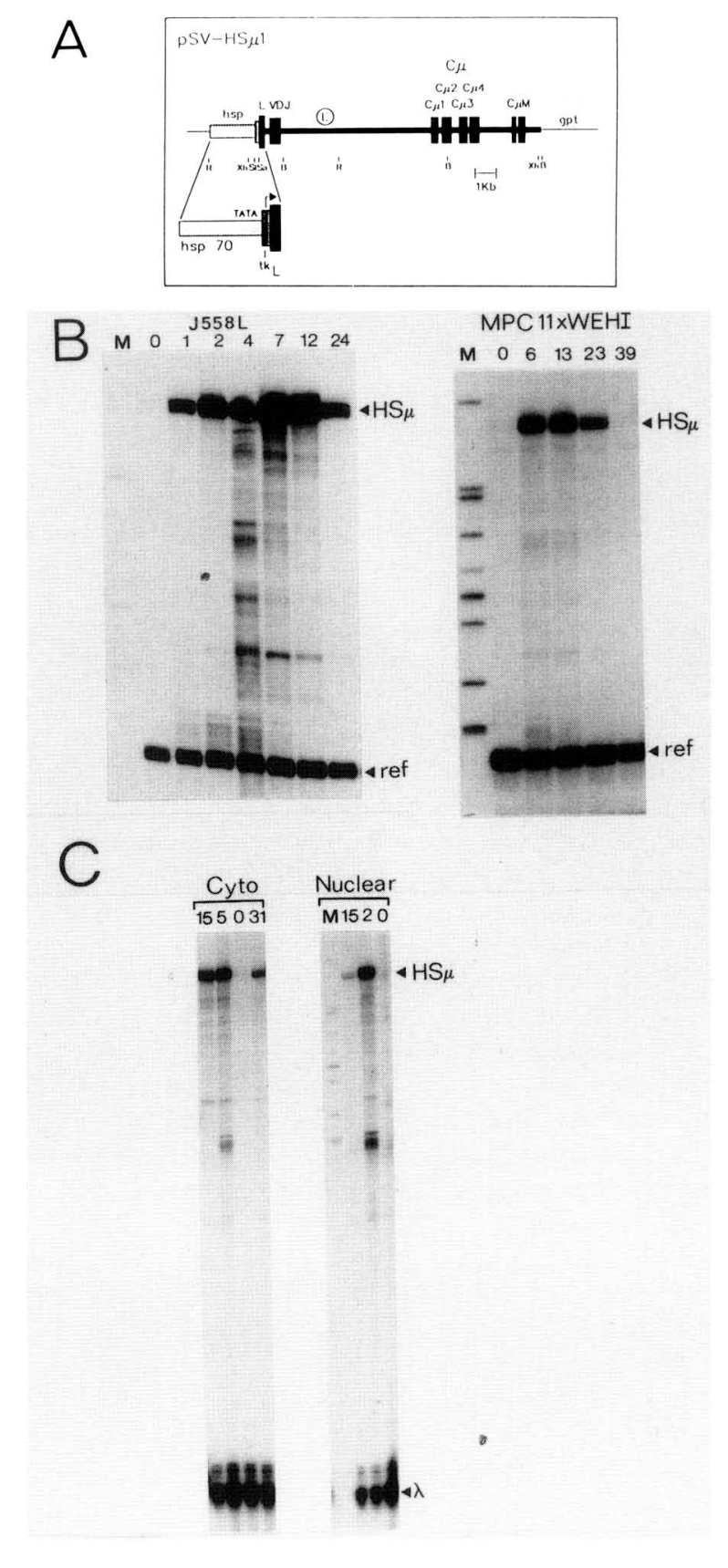

a control for an mRNA that should be exclusively on free polysomes. From the results (Fig. 5B), it can be seen that most of the $\mu$ mRNA in MPC $11 \times$ WEHI is found in the fraction isolated from membrane-bound polysomes, whereas the $\mu$ mRNA in WEHI231 is equally distributed between the free and membrane-bound fractions. A Northern blot (Fig. 1B) reveals that only $\mu_{m}$ and $\mu_{\mathrm{s}}$ mRNAs are observed in WEHI231 and MPC11 $\times$ WEHI, with no sign of sterile transcripts being detected. Therefore, the results presented here are consistent with the proposal that much of the $\mu$ mRNA exported from the nucleus of WEHI231 is not stabilized by being incorporated into membrane-bound polysomes. 

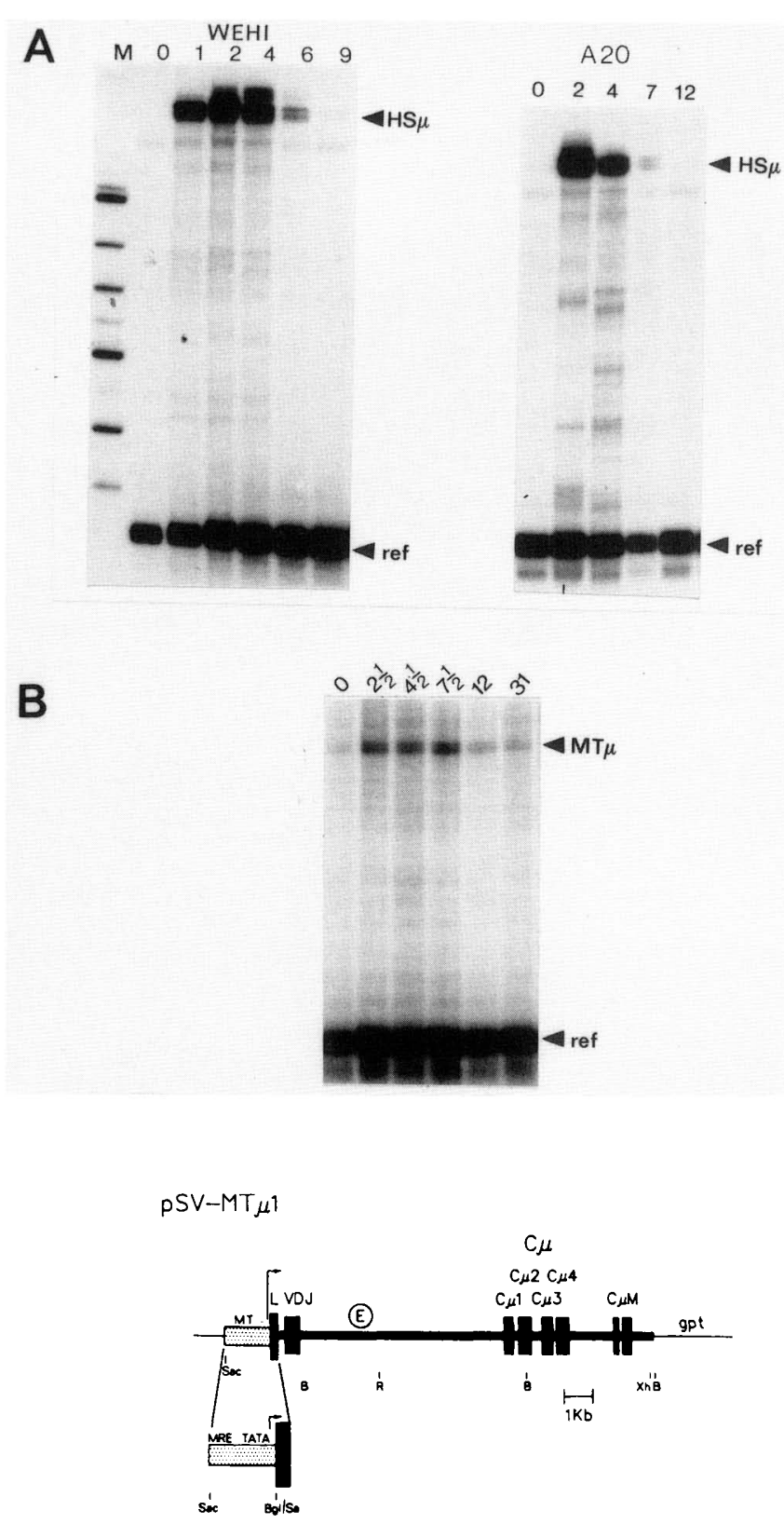

Figure 3. (A) Decay of newly synthesized $\mathrm{HS} \mu$ transcripts in transfected B lymphoma cells. pSV-HS $\mu 1$ transfectants of WEHI231 and A20 were heat-shocked at $41.5^{\circ} \mathrm{C}$ from $t=0$ to $t=1$, and cytoplasmic RNA was extracted at the times indicated and analyzed as indicated in the legend to Figure 2. $|B|$ Decay of newly synthesized MT $\mu$ transcripts in a pSV-MT $\mu 1$ transfectant of WEHI231. Plasmid pSV-MT $\mu 1$ is the same as pSV-V $\mu 1$ (Neuberger 1983), except that the $V_{\mathrm{H}}$ promoter region from the EcoRI site upstream of the promoter to the Sau3A site spanning the transcription start has been replaced by the SacIBgIII fragment of plasmid pMK2 (Brinster et al. 1982), which contains the metal response element of the mouse metallothionein 1 gene. At time $t=0$, cells were transferred to prewarmed medium containing $120 \mu \mathrm{M} \mathrm{ZnSO}_{4}$ and $10 \mu \mathrm{M} \mathrm{CdSO}{ }_{4} ;$ at $t=1$, cells were washed twice in warm saline supplemented to $0.5 \mathrm{mM}$ in EDTA and $1 \mathrm{mM}$ EGTA and further incubated at $37^{\circ} \mathrm{C}$ in medium containing $0.2 \mathrm{mM}$ EGTA.

\section{Discussion}

It is clear that post-transcriptional events play a major role in determining IgH mRNA levels (Gerster et al. 1986; Kelley and Perry 1986). From the work presented here, we can conclude that such post-transcriptional events are almost wholly responsible for effecting the increase in $\mu$ mRNA levels when we compare a hybridoma to a B-cell lymphoma. It is therefore attractive to postulate that during B-cell ontogeny, $\mathrm{IgH}$ transcription is initiated by activation of the enhancer (Gerlinger et al. 1986; Reik et al. 1987) but much of the subsequent modulation of mRNA levels is regulated by post-transcriptional events.

Post-transcriptional events have been shown to be important in regulating the cytoplasmic mRNA levels of several other genes (reviewed by Darnell 1982). In a few cases, the post-transcriptional regulation has been shown to occur at the level of the turnover of cytoplasmic mRNA [e.g., casein, vitellogenin, and adenovirus mRNAs (Guyette et al. 1979; Wiskocil et al. 1980; Wilson and Darnell 1981)]. Here, we have investigated the turnover of IgH mRNA in B-cell lymphoma and a plasmacytoma. We have accomplished this by analyzing the disappearance of $\mu$ transcripts whose synthesis in transfected cells is under the control of inducible promoters (heat shock or metallothionein). In different experiments, we obtained estimates for the half-life in two plasmacytomas as being between 12 and $20 \mathrm{hr}$, whereas the value is estimated at between 2.4 and $3.5 \mathrm{hr}$ in the B-cell lymphoma. Although the stability of $\mu$ mRNA in B-cell lymphomas has not been measured previously, experiments have been carried out to measure the rate of turnover of mRNA in plasmacytoma. Storb (1973) estimated the half-life of total microsomal poly $\mid A)^{+}$RNA in the myeloma MOPC21 (P3K) as $44 \mathrm{hr}$, whereas Cowan and Milstein (1974) measured the turnover of total poly $(\mathrm{A})^{+}$RNA isolated from membrane-bound polysomes of the same myeloma as between 12 and $14 \mathrm{hr}$. Clearly, these investigators have estimated the half-lives of a mixed population of mRNAs, although a large proportion of the RNA in the samples examined by Cowan and Milstein is likely to have been $\kappa$ mRNA.

In view of the considerable difference in morphology exhibited by a $B$ cell and a plasma cell when examined in the electron microscope, it was attractive to postulate that the expansion of the secretory apparatus plays a role in the stabilization of IgH mRNA. This proposal is supported by our demonstration that a mutated $\mu$ mRNA that is translated on free (as opposed to membranebound) polysomes has a shortened half-life in plasmacytoma, comparable to that of the wild-type mRNA in a B-cell lymphoma. Thus, the proliferation of endoplasmic reticulum may be responsible for mediating the increase in the steady-state level of $\operatorname{IgH} \mathrm{mRNA}$ on differentiation of a B cell into a plasma cell. Consistent with this proposal is the finding that a larger proportion of $\mu$ mRNA is found on membrane-bound polysomes in a plasmacytoma than in a B-cell lymphoma. [An analogous observation was made in a different context by Zuniga et al. (1982), who noted that although most of the $\mu$ mRNA in 
Figure 4. Decay of $H S \mu$ mRNA. The results of three independent inductions using cloned pSV$\mathrm{HS} \mu \mathrm{l}$ transfectants of $\mathrm{J558 \textrm {L }}$ (circles and solid lines) or WEHI231 (squares and dashed lines) were monitored by RNase protection assays, quantitated by densitometry of autoradiographs, controlled for the hybridization to the reference probe, and plotted out after correcting for cell division, assuming exponential growth. Solid from the experiments depicted in Figure $2(B)$ and 3|A). The cell doubling time of J558L was $21 \mathrm{hr}$; that of WEHI231 was $19 \mathrm{hr}$. The table below the chart gives a summary of the half-lives determined for $\mu$ and $\mu^{\star}$ mRNAs. circles and squares denote the curves obtained

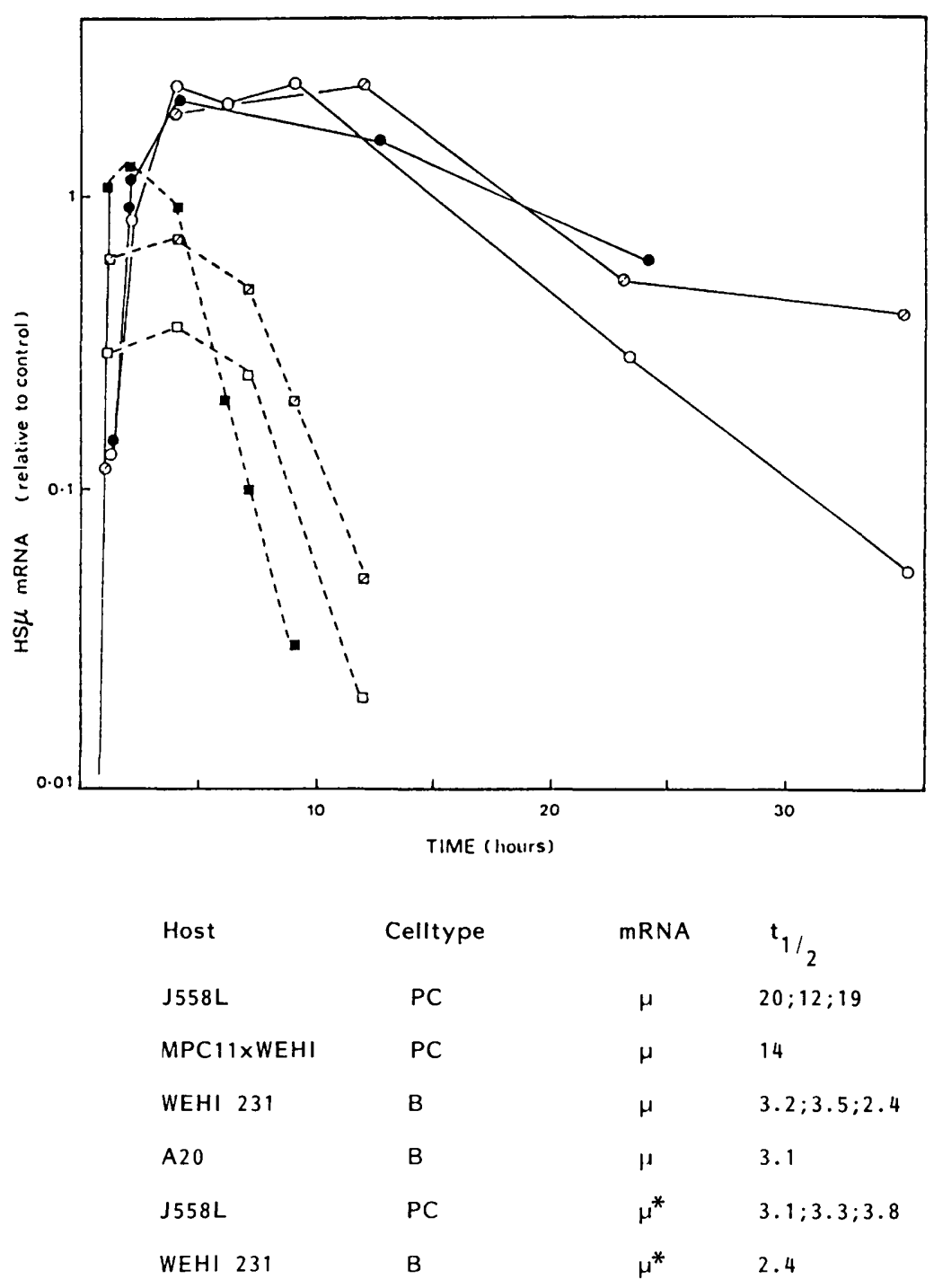

a hybridoma was located on membrane-bound polysomes, the corresponding figure was only $50 \%$ in the two T-cell lines.] In fact, an indication that translatability or that sequences at the $5^{\prime}$ end of $\mu$ mRNA play a role in modulating the increase in its steady-state levels is available from the work of Kelley and Perry (1986), who observed that the abundance of sterile $\mu$ transcripts is no greater in plasmacytomas than it is in B-cell lymphomas.

If such a model is correct, it would seem reasonable to extrapolate from these results and predict that the level of other mRNAs found on membrane-bound polysomes might increase in an analogous manner to IgH transcripts on differentiation of a B cell into a plasma cell. We know nothing about the mechanism of degradation of long-lived mRNAs, but one might expect stabilization by targeting to membrane-bound polysomes to depend on the sequence and secondary structure of the transcript under consideration. Although the amounts of several gene products are known to change on B-cell to plasma cell differentiation, as yet no other mRNA found on membrane-bound polysomes has been demonstrated to increase in abundance during this transition as a consequence of increased mRNA half-life. Interestingly, however, a link between the abundance of endoplasmic reticulum and the levels of mRNAs for secreted proteins is indicated by work in another system, the regulation of the expression of parotid secretory protein. In this case, post-transcriptional events play an important role in determining cytoplasmic mRNA levels, and it has been observed that the level of the mRNA for parotid secretory protein increases concomitantly with an increase in the proportion of acinar cells in the developing mouse parotid that contain an extensive array of endoplasmic reticulum (Shaw et al. 1986). Nevertheless, final demonstration that cell-type-specific changes in the steadystate levels of mRNAs for secreted proteins can result from an increase in the amount of endoplasmic retic- 

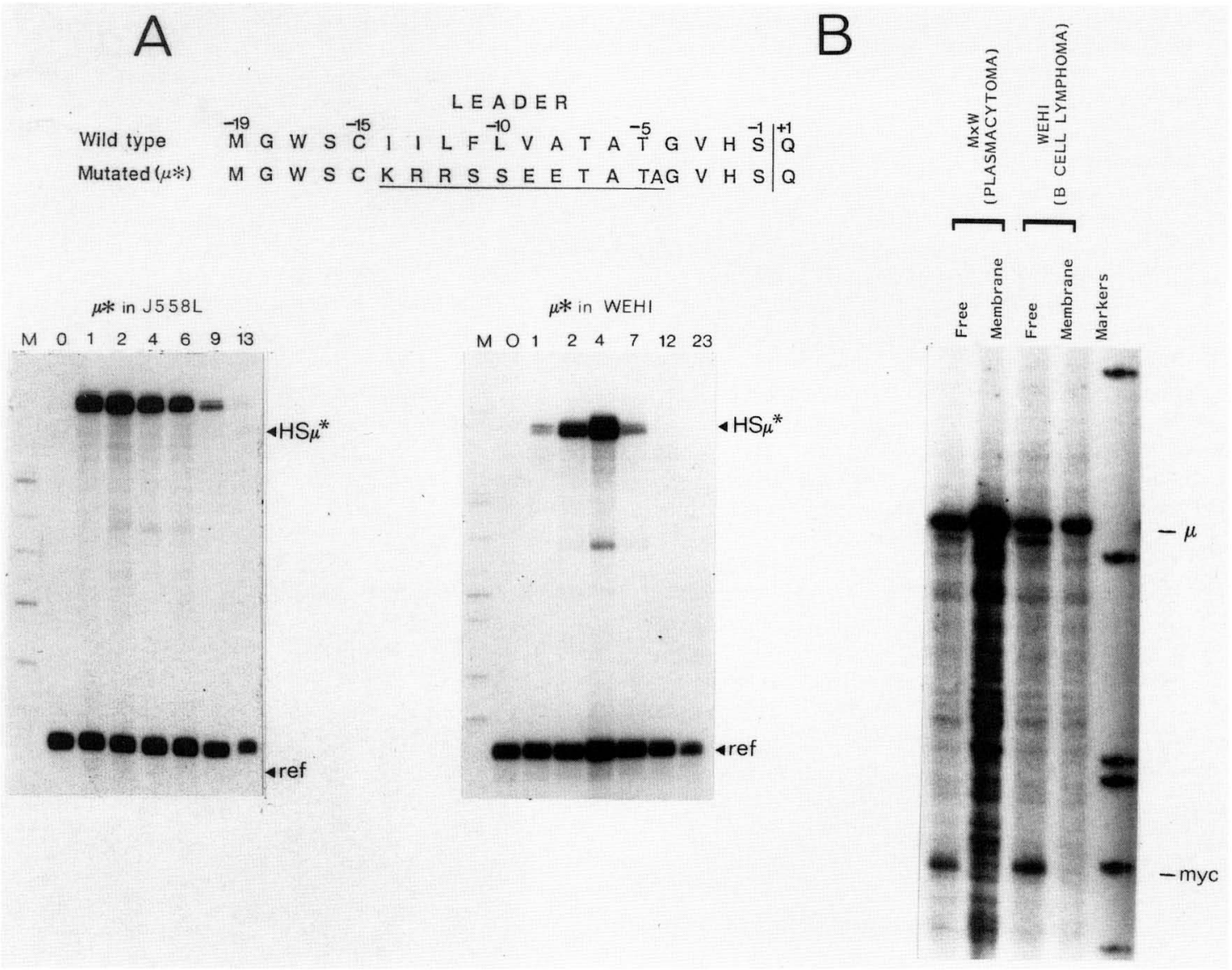

Figure 5. (A) Decay of newly synthesized $\mu^{\star}$ RNA in pSV-HS $\mu^{*}$ transfectants of J558L and WEHI231. The leader sequence of $\mu$ * chains is compared to the wild-type, with the first amino acid of secreted $\mu$ chains being designated position $+1 . \mu^{\star}$ and reference RNA were measured following heat induction of cloned transfectants, as described in the legend to Figure 1. $(B)$ Steady-state distribution of $\mu$ mRNA between free and membrane-bound polysomes. RNA was extracted from membrane-bound and free polysomes that had been prepared from exponentially growing 2-liter cultures of $\mathrm{MPC} 11 \times \mathrm{WEHI}(\mathrm{M} \times \mathrm{W})$ and WEHI231. RNase protection assays were used to measure $\mu$ and c-myc transcripts in the different fractions. Of the total RNA in the two MPC11 x WEHI fractions, $0.3 \%$ was used $(2 \mu \mathrm{g}$ from free and $0.6 \mu \mathrm{g}$ from the membrane-bound fraction), whereas $0.4 \%$ was used from WEHI231 (2 $\mu \mathrm{g}$ from free and $0.4 \mu \mathrm{g}$ from the membrane-bound fraction). The $\mu$ probe monitors transcripts spanning the $\mathrm{C} \mu 1$ exon, whereas the $c-m y c$ probe derives from the $3^{\prime}$ end of c-myc exon 2.

ulum could be best achieved by transfecting a test gene provided with different $5^{\prime}$ sequences into different cell types and measuring the resultant steady-state levels of the transcripts.

\section{Materials and methods}

Cell lines, plasmids, and transfections

Plasmacytoma J558L (Oi et al. 1983) and the MPC11 $\times$ WEHI231 hybridoma $M \times$ W231.1a (Raschke et al. 1979) were maintained in DMEM/10\% fetal calf serum (FCS). Pre-B cell line 18-81 (Siden et al. 1979) and B-cell lymphomas WEHI231 (Gutman et al. 1981) and A20 [(Kim et al. 1979), provided by $\mathrm{A}$. Venkitaraman] were maintained in the same medium supplemented to $50 \mu \mathrm{M}$ in 2-mercaptoethanol.

Plasmids pSV-HS $\mu 1$ and pSV-MT $\mu 1$ are described in Figures 2 and 3; plasmid pSV-HS $\mu$ * (Fig. $5 \mathrm{~A}$ ) is a derivative of pSV-HS $\mu 1$ and was created by site-directed mutagenesis using an M13 subclone and the oligonucleotide 5'-CTGTAGCTGTTTC-
TTCCGAGGAGCGCCTCTTACAGCTCCATC-3' , which was synthesized by Terry Smith on an Applied Biosystems machine.

Cells were transfected by spheroplast fusion (Neuberger and Williams 1986) or electroporation (Potter et al. 1984). Stable transfectants were selected in medium containing $5 \mu / \mathrm{ml} \mathrm{my-}$ cophenolic acid, $13.6 \mu \mathrm{g} / \mathrm{ml}$ hypoxanthine, and $0.25 \mathrm{mg} / \mathrm{ml}$ xanthine. Aminopterin $(3.5 \mathrm{ng} / \mathrm{ml})$ and thymidine $(3.8 \mu \mathrm{g} / \mathrm{ml})$ were also included for the selection of WEHI231 transfectants. Cells were cloned by limiting dilution in the absence of feeder cells.

\section{Preparation and analysis of RNA}

The preparation of cytoplasmic (Neuberger 1983), nuclear (Scherrer 1969), and total cell RNA (Treisman 1985), as well as Northern blot analysis (Thomas 1983) of RNA fractionated in formaldehyde/agarose gels (Lehrach et al. 1977) and ribonuclease protection assays (Melton et al. 1984), was carried out as described. The probes used for mapping $\mathrm{HS} \mu, \mathrm{MT} \mu$, and $\mathrm{HS} \mu{ }^{*}$ 
transcripts were made from derivatives that lacked the leader $V_{\mathrm{H}}$ intron and extended from the StuI site (codon +40 of $V_{\mathrm{H}}$ ) back across the transcription start site to the $S p h I$ site in the hsp70 promoter or the SacI site in the metallothionein promoter. SP6 probes for heat shock cognate and $\mu$ and c-myc RNAs were made from subclones in pSP64 or pSP65; the probes comprised the 200-bp NarI fragment that includes the translation termination codon of the cDNA insert of plasmid pMHS213 (Lowe and Moran 1986), the XbaI-SacI fragment encompassing $\mathrm{C} \mu \mathrm{l}$, and the PstI-SacI fragment spanning the exon 2/intron 2 border of c-myc (Neuberger and Calabi 1983), respectively.

The preparation of membrane-bound and free polyomes is based on a procedure described by Harrison et al. (1974). Exponentially growing cells from 2 liters of culture were pelleted, resuspended in $200 \mathrm{ml}$ of prewarmed $\left(37^{\circ} \mathrm{C}\right)$ medium containing $2 \mu \mathrm{g} / \mathrm{ml}$ cycloheximide, incubated at $37^{\circ} \mathrm{C}$ for $15 \mathrm{~min}$, and chilled rapidly prior to pelleting, washing with phosphate-buffered saline/cycloheximide, and freezing at $-70^{\circ} \mathrm{C}$. Cells were thawed in $320 \mathrm{mM}$ sucrose $/ 3 \mathrm{~mm} \mathrm{MgCl}_{2} /$ cycloheximide, lysed by cavitation, and the nuclei removed by centrifugation. The microsomal fraction was separated by centrifugation at 17,000 rpm for $10 \mathrm{~min}$ in MSE-18 tubes and resuspended in HSB buffer (50 mM Tris- $\mathrm{HCl}, 250 \mathrm{mM} \mathrm{KCl}, 2 \mathrm{~mm} \mathrm{MgCl}_{2}$ ) containing $10 \%$ Nonidet P-40. Polysomes were purified from the microsomal and free fraction by centrifugation $4.5 \mathrm{hr}$ at $45,000 \mathrm{rpm}$ in a Beckman Ti60 rotor) through sucrose cushions (1.6 $\mathrm{M}$ sucrose in HSB). RNA was prepared from the pelleted polysome samples by phenol/ $\mathrm{CHCl}_{3}$ extraction and ethanol precipitation.

\section{Nuclear runoff assays}

The preparation of nuclei from exponentially growing cells by Dounce homogenization and centrifugation through $2 \mathrm{M}$ sucrose, as well as the incorporation reactions $\left(10^{7}\right.$ nuclei incubated at $30^{\circ} \mathrm{C}$ for $5 \mathrm{~min}$ with $\left.150 \mu \mathrm{Ci}\left[\alpha^{-32} \mathrm{P}\right] \mathrm{UTP}\right)$, was carried out as described by Marzluff and Huang (1985). Reactions were terminated by the addition of 5 units of RNase-free DNase (Promega) and 40 units RNasin (Promega), and the incubation continued at $37^{\circ} \mathrm{C}$ for $10 \mathrm{~min}$. Reactions were diluted with 300 $\mu \mathrm{l} 1 \%$ SDS, $5 \mathrm{~mm}$ EDTA, $10 \mathrm{~mm}$ Tris- $\mathrm{HCl}(\mathrm{pH} 7.4)$, and 0.3 $\mathrm{mg} / \mathrm{ml}$ proteinase $\mathrm{K}$ and incubated for an additional $15 \mathrm{~min}$ at $37^{\circ} \mathrm{C}$. After two extractions with phenol $/ \mathrm{CHCl}_{3}, \mathrm{RNA}$ was precipitated by the addition of 0.4 volumes of ammonium acetate and an equal volume of isopropanol. Labeled RNA was split proportionally $1: 2: 4$, and the aliquots were hybridized to DNA dots $(5 \mu \mathrm{g})$ on nitrocellulose, as described by Greenberg and Ziff (1984). Filters were washed four times with $2 \times$ SSC for $30 \mathrm{~min}$ at $65^{\circ} \mathrm{C}$, incubated for $30 \mathrm{~min}$ at $37^{\circ} \mathrm{C}$ with $10 \mu \mathrm{g} / \mathrm{ml}$ RNase $\mathrm{A}$, and washed again in $2 \times \mathrm{SCC}$ at $37^{\circ} \mathrm{C}$ for $30 \mathrm{~min}$, air-dried, and exposed to film. For quantitation, the relative amounts of ${ }^{32} \mathrm{P}$ hybridized to each probe were determined by quantitative densitometric scanning of autoradiographs. The signal was plotted against input radioactivity, and the gradient of this line was divided by the length of the hybridizing sequence; allowance was made for the proportion of $U$ residues in the RNA where sequences were known. The values obtained with the probes across the IgH locus were then divided by an average of the values obtained using the probes for the genes encoding metabolic enzymes. The whole experiment was carried out three times.

\section{Acknowledgments}

We thank Drs. Breathnach and Raschke for gifts of plasmids and cell lines, Angela Cox and Roberto Sitia for discussions, and Franco Calabi for helpful criticism of the manuscript.

\section{References}

Banerii, J., L. Olson, and W. Schaffner. 1983. A lymphocyte-specific cellular enhancer is located downstream of the joining region in immunoglobulin heavy chain genes. Cell 33: 729740.

Brinster, R.L., H.Y. Chen, R. Warren, A. Sarthy, and R.D. Palmiter. 1982. Regulation of metallothionein-thymidine kinase fusion plasmids injected into mouse eggs. Nature 296: 39.

Calabi, F. and M.S. Neuberger. 1985. Chromosomes translocation activates heterogeneously initiated, bipolar transcription of a mouse c-myc gene. EMBO I. 4: 667-674.

Cowan, N.J. and C. Milstein. 1974. Stability of cytoplasmic ribonucleic acid in a mouse myeloma: Estimation of the halflife of the messenger RNA coding for an immunoglobulin light chain. J. Mol. Biol. 82: 469-481.

Darnell, J.E. 1982. Variety in the level of gene control in eukaryotic cells. Nature 297: 365-371.

Gerlinger, P., M. LeMeur, C. Irrmann, P. Renard, C. Wasylyk, and B. Wasylyk. 1986. B-lymphocyte targeting of gene ex pression in transgenic mice with the immunoglobulin heavy-chain enhancer. Nucleic Acids Res. 14: 6565-6567.

Gerster, T., D. Picard, and W. Schaffner. 1986. During B-cell differentiation enhancer activity and transcription rate of immunoglobulin heavy chain genes are high before mRNA accumulation. Cell 45: 45-52.

Gillies, S.D., S.L. Morrison, V.T. Oi, and S. Tonegawa. 1983. A tissue-specific transcription enhancer element is located in the major intron of a rearranged immunoglobulin heavy chain gene. Cell 33: 717-728.

Greenberg, M.E. and E.B. Ziff. 1984. Stimulation of 3T3 cells induces transcription of the c-fos proto-oncogene. Nature 311: $433-438$.

Grosschedl, R. and D. Baltimore. 1985. Cell-type specificity of immunoglobulin gene expression is regulated by at least three DNA sequence elements. Cell 41: 885-897.

Gutman, G.A., N.L. Warner, and A.W. Harris. 1981. Immunoglobulin production by murine B-lymphoma cells. Clin. Immunol. Immunopathol. 18: 230-244.

Guyette, W.A., R.J. Matusik, and J.M. Rosen. 1979. Prolactinmediated transcriptional and post-transcriptional control of casein gene expression. Cell 17: 1013-1023.

Harrison, T.M., G.G. Brownlee, and C. Milstein. 1974. Studies on polysome-membrane interactions in mouse myeloma cells. Eur. J. Biochem. 47: 613-620.

Kelley, D.E. and R.P. Perry. 1986. Transcriptional and posttranscriptional control of immunoglobulin mRNA production during B lymphocyte development. Nucleic Acids Res. 14: $5431-5446$.

Kim, K.J., C. Kanellopoulos-Langevin, R.W. Merwin, D.H. Sachs, and R. Asofsky. 1979. Establishment and characterisation of BALB/c lymphoma lines with B cell properties. $J$. Immunol. 122: 549-554.

Lehrach, H., D. Diamond, J. Wozney, and H. Boedtker. 1977. RNA molecular weight determinations by gel electrophoresis under denaturing conditions, a critical evaluation. Biochemistry 16: 4743-4751.

Lennon, G.G. and R.P. Perry. 1985. C $\mu$-containing transcripts initiate heterogeneously within the IgH enhancer region and contain a novel 5'-nontranslatable exon. Nature 318: 475478.

Lowe, D.G. and L.A. Moran. 1986. Molecular cloning and analysis of DNA complementary to three mouse $M_{r}=68,000$ heat shock protein mRNAs. J. Biol. Chem. 261: 2102-2112. Marzluff, W.F. and R.C.C. Huang. 1985. Transcription of RNA 
in isolated nuclei. In Transcription and translation, a practical approach (ed. B.D. Hames and S.J. Higgins), pp. 89-129. IRL Press, Oxford.

Mason, J.O., G.T. Williams, and M.S. Neuberger. 1985. Transcription cell type specificity is conferred by an immunoglobulin $\mathrm{V}_{\mathrm{H}}$ gene promoter that includes a functional consensus sequence. Cell 41: 479-487.

Matrisian, L.M., G. Rautmann, B.E. Magun, and R. Breathnach. 1985. Epidermal growth factor or serum stimulation of rat fibroblasts induces an elevation in mRNA levels for lactate dehydrogenase and other glycolytic enzymes. Nucleic Acids Res. 13: 711-726.

Melton, D.A., P.A. Krieg, M.R. Rebagliati, T. Maniatis, K. Zinn, and M.R. Green. 1984. Efficient in vitro synthesis of biologically active RNA and RNA hybridization probes from plasmids containing a bacteriophage SP6 promoter. Nucleic Acids Res. 12: 7035-7056.

Neuberger, M.S. 1983. Expression and regulation of an immunoglobulin heavy chain gene transfected into lymphoid cells. EMBO J. 2: 1373-1378.

Neuberger, M.S. and F. Calabi. 1983. Reciprocal chromosome translocation between $\mathrm{c}-m y c$ and immunoglobulin $\gamma 2 \mathrm{~B}$ genes. Nature 305: 240-243.

Neuberger, M.S. and G.T. Williams. 1986. Protein engineering of antibody molecules. In Protein engineering: Applications in science, medicine and industry (ed. M. Inouye and $\mathrm{R}$. Sarma), pp. 311-317. Academic Press, New York.

Oi, V.T., S.L. Morrison, L.A. Herzenberg, and P. Berg. 1983. Immunoglobulin gene expression in transformed lymphoid cells. Proc. Natl. Acad. Sci. 80: 825-829.

Pelham, H.R.B. 1982. A regulatory upstream promoter element in the Drosophila hsp70 heat-shock gene. Cell 30: 517-528.

Perry, R.P. and D.E. Kelley. 1979. Immunoglobulin messenger RNAs in murine cell lines that have characteristics of immature B lymphocytes. Cell 18: 1333-1339.

Potter, H., L. Weir, and P. Leder. 1984. Enhancer-dependent expression of human $\kappa$ immunoglobulin genes introduced into mouse pre-B lymphocytes by electroporation. Proc. Natl. Acad. Sci. 81: 7161-7165.

Raschke, W.C., E.L. Mather, and M.E. Koshland. 1979. Assembly and secretion of pentameric IgM in a fusion between a nonsecreting B cell lymphoma and an IgG-secreting plasmacytoma. Proc. Natl. Acad. Sci. 76: 3469-3473.

Reik, W., G. Williams, S. Barton, M. Norris, M. Neuberger, and M.A. Surani. 1987. Provision of the immunoglobulin heavy chain enhancer downstream of a test gene is sufficient to confer lymphoid-specific expression in transgenic mice. Eur. I. Immunol. 17: 465-469.

Richards, J.E., A.C. Gilliam, A. Shen, P.W. Tucker, and F.R. Blattner. 1983. Unusual sequences in the murine immunoglobulin $\mu-\delta$ heavy-chain region. Nature 306: 483-487.

Scherrer, K. 1969. Isolation and sucrose gradient analysis of RNA. In Fundamental techniques in virology (ed. K. Habel and N. Salzman), pp. 413-432. Academic Press, New York.

Shaw, P., B. Sordat, and U. Schibler. 1986. Developmental coordination of $\alpha$-amylase and $p s p$ gene expression during mouse parotid gland differentiation is controlled post-transcriptionally. Cell 47: 107-112.

Siden, E.J., D. Baltimore, D. Clark, and N.E. Rosenberg. 1979. Immunoglobulin synthesis by lymphoid cells transformed by Abelson murine leukemia virus. Cell 16: 389-396.

Sitia, R., M.S. Neuberger, and C. Milstein. 1987. Regulation of IgM expression in secretory B cells: Translational and posttranslational events. EMBO /. 6: 3969-3977.

Storb, U. 1973. Turnover of myeloma messenger RNA. Biochem. Biophys. Res. Commun. 52: 1483-1491.
Thomas, P.S. 1983. Hybridization of denatured RNA transferred or dotted to nitrocellulose paper. Methods Enzymol. 100: $255-266$.

Treisman, R. 1985. Transient accumulation of c-fos RNA following serum stimulation requires a conserved $5^{\prime}$ element and c-fos 3' sequences. Cell 42: 889-902.

Wilson, M.C. and J.E. Darnell. 1981. Control of messenger RNA concentration by differential cytoplasmic half-life: Adenovirus messenger RNAs from transcription units $1 \mathrm{~A}$ and $1 \mathrm{~B}$. J. Mol. Biol. 148: 231-251.

Wiskocil, R., P. Bensky, W. Dower, R.F. Goldberger, J.I. Gordon, and R.G. Deeley. 1980. Coordinate regulation of two estrogen-dependent genes in avian liver. Proc. Natl. Acad. Sci. 77: 4474-4478.

Zuniga, M.C., P. D'Eustachio, and N.H. Ruddle. 1982. Immunoglobulin heavy chain gene rearrangement and transcription in murine T cell hybrids and T lymphomas. Proc. Natl. Acad. Sci. 79: 3015-3019. 


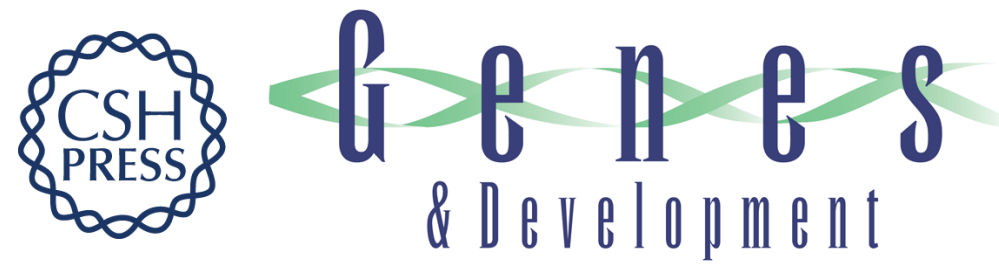

\section{The half-life of immunoglobulin mRNA increases during B-cell differentiation: a possible role for targeting to membrane-bound polysomes.}

J O Mason, G T Williams and M S Neuberger

Genes Dev. 1988, 2:

Access the most recent version at doi:10.1101/gad.2.8.1003

References This article cites 39 articles, 7 of which can be accessed free at:

http://genesdev.cshlp.org/content/2/8/1003.full.html\#ref-list-1

License

Email Alerting

Service

Receive free email alerts when new articles cite this article - sign up in the box at the top right corner of the article or click here.

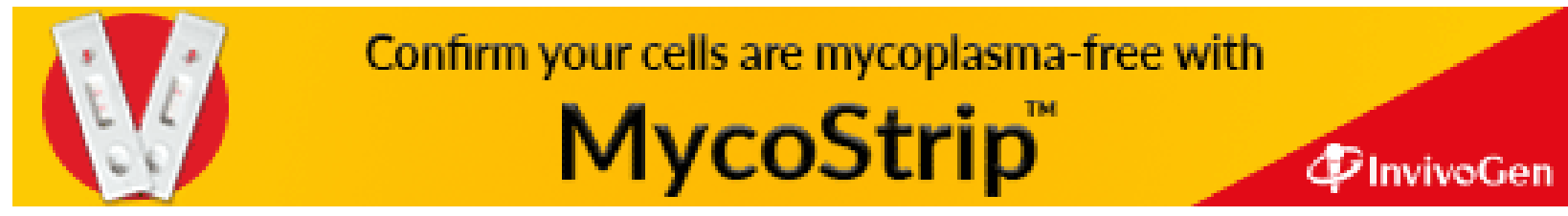

